\title{
Taxonomic studies in Euphrasia (Scrophulariaceae). VIII. E. ruptura, a name for a species apparently extinct in northeastern New South Wales
}

\author{
W.R. Barker
}

\begin{abstract}
Barker. W.R. (State Herbarium, Botanic Gardens of Adelaide, North Terrace, Adelaide, South Australia, 5000) 1997. Taxonomic studies in Euphrasia (Scrophulariaceae). VIII. E. ruptura, a name for a species apparently extinct in northeastern New South Wales. Telopea 7(3): 227-230. The name E. ruptura and a description are provided for this species from Tamworth, northeastern New South Wales, which has been recognised since 1982 by an informal phrase name. Despite efforts to find it, it is still only known from the two flowering branches collected in 1904 and remains most likely to be extinct.
\end{abstract}

\section{Introduction}

Since the existence of a new species from the Tamworth area was publicised by an informal phrase name 15 years ago (Barker 1982), efforts made to rediscover it (Ms P. Horton, pers. comm. 1996) have been unsuccessful. It remains apparently extinct. Discovery of a wider range of material than the two flowering branches of the single known collection would have enabled a better documentation of the variability of the new species and assessment of its diagnostic features. A similar delay in formal publication of the endangered southeast Tasmania E. fragosa (Barker 1982) may have assisted, for example, in promoting the species' rediscovery and discovery of a new population (Collier 1990). This resulted in a better assessment of its taxonomic integrity, variation and diagnostic traits (Barker 1996).

Though brought earlier to the attention of national compilers of lists of endangered species (Barker 1982 and in correspondence), the Tamworth species was finally given a conservation status of $1 \mathrm{X}$ in the national censuses of rare and endangered plant taxa when informal taxa were accepted (Briggs \& Leigh 1988, 1996). The numeric component of the status coding has indicated that the species is known from the one collection, the alphabetic that it has been believed to be extinct.

The species is now being formally named to enable its inclusion in endangered species legislation in New South Wales (Ms J. Everett, pers. comm. 1996).

\section{Description}

Euphrasia ruptura W.R. Barker, sp. nov.

[Euphrasia sp. 'Tamworth': W.R. Barker, J. Adel. Bot. Gard. 5 (1982) 156, fig. 49, 57; Briggs \& Leigh, Rare or Threatened Australian Plants (1988) 101, 193, as Euphrasia sp. 1 (Tamworth); Briggs \& Leigh, Rare threat. Austral. pl., 1995 edn (1996) 175, 209, as Euphrasia sp. 1 (Tamworth: Rupp s.n., 09/1904). ] 
Species nova Sectionis Australium E. bellae et E. bowdeniae affinissime inflorescentiis laxis nodibus saepe unifloribus; ab E. bella differt pilis glandulosis e ramulis foliisque carentibus, foliis reflexis angustioribus base anguste cuneata et dentibus marginalibus brevioribus, calyce breviori, et antheris minoribus aristis postremis brevioribus, ab E. bowdeniae pilis eglandulosis ramos aeque et plus minusve dense cingentibus, et foliis dentibus marginalibus pluribus.

Type: New South Wales: North-western Slopes: Tamworth, [H.M.R. Rupp], MEL 41404, Sep 1904. (Holotypus: MEL; iconotypus:Barker 1982, fig. 57).

Apparently a perennial subshrub, over $26 \mathrm{~cm}$ high; branchlets with more than 22-25 pairs of leaves (Note 2), surrounded over whole length by moderately dense to dense, retrorse scaberulous eglandular hairs c. $0.05 \mathrm{~mm}$ long; shoots or young branches occurring sporadically in leaf axils up to $2-5$ nodes below the inflorescence, in groups of $2-5$ nodes, with no buds for several nodes between, the internodes $2-5$ nodes below the inflorescence longer than the subtending leaf, shorter below. Leaves reflexed, at least in the material seen (Notes 2,3), narrow oblong, covered by sparse to moderately dense, antrorse minutely scaberulous eglandular hairs c. $0.02 \mathrm{~mm}$ long; uppermost $0.6-1.3 \mathrm{~cm} \times 1.0-1.5 \mathrm{~mm}$; base narrow cuneate; teeth 2 pairs, $0.2-0.3 \mathrm{~mm}$ long; apex $1.3-1.5 \times$ c. $0.8 \mathrm{~mm}$, blunt acute; lower leaves similar, the longest seen 1.3-1.9 cm $\times 1.2-1.8 \mathrm{~mm}$ with rare instances of 3 pairs of teeth; sessile gland patches narrow, extending almost to the base of the leaf. Inflorescences erect, relatively compact with flowers spaced at lower nodes, at the third node the flower reaching past the node above, the nodes above the inflorescence without buds (see Note 5) and sometimes the nodes bearing only one flower; rachis retrorsely eglandular scaberulous all around like the branches; flowers c. 8 in specimens seen; bracts like the upper leaves, but with 1-2 pairs of teeth; pedicels $2.5-4 \mathrm{~mm}$ long, ascending, retrorsely eglandular scaberulous all around. Calyx 3.8-4.5 mm long, with scattered spreading or slightly antrorse very short eglandular hairs c. $0.05 \mathrm{~mm}$ long, the teeth bluntly acute, covered inside by moderately dense, antrorse, scaberulous, eglandular hairs; median clefts $1.5-1.8 \mathrm{~mm}$ long, lateral clefts $0.8-1.1 \mathrm{~mm}$ long. Corolla $8.0-10.8 \mathrm{~mm}$ long along the upper side, of unknown colour; tube c. $5.0 \mathrm{~mm}$ long, narrow cylindrical for c. $4.5 \mathrm{~mm}$ to the base of the anterior filaments, distally broadened, externally glabrous at the base, distally in exposed parts covered by dense long eglandular hairs; hood 2.0-2.5 mm long, externally covered by dense long eglandular hairs mixed with scattered moderately long to long glandular hairs; upper lobes emarginate, with front surface glabrous, with cleft between c. $1.3 \mathrm{~mm}$ deep; lower lip c. 5.0-9.0 long, downturned from about the base of the lobes, covered externally by dense long eglandular hairs mixed with scattered moderately long to long glandular hairs; lower lobes shallowly emarginate, with cleft between $3.2-4.0 \mathrm{~mm}$ deep. Stamens with anthers c. $1.3 \times 1.1 \mathrm{~mm}$, with connectives surrounded by dense long eglandular hairs; rearmost pair of awns c. $0.2-0.25 \mathrm{~mm}$ long, the other 6 awns c. $0.1 \mathrm{~mm}$ long. Ovary not seen. Young fruits ovate-elliptic in lateral view; apex broadly obtuse in lateral view, with 1 or 2 setae.

Distribution: E. ruptura is known from a single collection from Tamworth in the Northern Tablelands (New England) region of New South Wales (Barker 1982, fig. 49).

Ecology: nothing is known of its ecology, although it may share the cliff face or cliff edge habitat of its closest relatives E bowdeniae and E. bella.

Conservation status: 1X (Briggs \& Leigh 1996). As mentioned, endeavours to discover this species in the Tamworth area have proved fruitless.

Notes: 1. As indicated in Barker (1982), this species is closest allied to two species of Sect. Australes, E. bella S.T. Blake of the ranges in the Tweed River watershed to the north and E. bowdeniae W.R. Barker of the Blue Mountains to the south, by its lax inflorescences, often with a single flower at a node. Ovule number has not been 
determined owing to the paucity of material available; this is lower in E. bella and E. bowdeniae than for other members of Sect. Australes (Barker 1982). From E. bella it differs by the absence of glandular hairs on the branches and upper leaves, by its reflexed narrower leaves with a narrowly cuneate base and shorter marginal teeth, by its shorter calyx, and by its shorter anthers with shorter rearmost awns. From E. bowdeniae it is separated by eglandular hairs distributed completely and evenly around the branchlets, and by its leaves immediately below the inflorescence with two teeth along each margin.

2. Measurements in the description of length and number of leaves on main inflorescence-bearing branches represent measurements from the two flowering branches in the type and are clearly less than the actual value for these specimens. The branches have apparently been plucked from above their base; in Euphrasia leaves towards the base of such branches are much shorter and the internodes reduced in length compared with the distal parts.

3. Deflexed leaves, which I have observed arising from branches pendent from sheer cliff faces in E. bowdeniae, are also evident in E. ruptura. Contrary to Barker (1982), however, plants of E. bella observed in 1989 on the forest floor in the MacPherson Range had ascending to decumbent branches with ascending leaves, more typical of Australian perennials in the genus.

4. Measurements of the flower were taken from flowers in the dried state because of the limited material available, whereas I have used in the past spirit or soaked material; this will result in slightly shorter measurements in comparison with previous descriptions. Also as a result the internal indumentum of the corolla, hood and lower lip width and filament lengths have not been described.

5. No buds are apparent in a number of leaves distal of the inflorescences in each branch seen. It is uncertain whether the rachis of the inflorescence continues after flowering into a vegetative phase, as in Sect. Phragmostomae of southeastern Tasmania (Barker 1982, 1987) or whether the inflorescences terminate the branch, the normal situation in Euphrasia and in this instance the related E. bella and E. bowdeniae.

6. The species epithet is a noun in apposition. It has two meanings. On the one hand it commemorates in a play on words H.M.R. Rupp, an important collector of plants in general in New South Wales and Victoria, later specialising in Orchidaceae (Clarke 1990); the type specimen comes from the period when he first began to collect plants seriously, in Tamworth in 1903-4. On the other hand the epithet is a Latin substantive, meaning literally the result of the breaking up, referring both to the three closely related species recognised in revisional study since the 1980s, and to the lineal stepped variation and disjunct geography of this group of three species.

\section{Acknowledgments}

I thank Ms Joy Everett for encouragement to publish the species and the National Herbarium of Victoria (MEL) for access to the sole collection and facilities for its measurement. Ms Karen Wilson of the University of Melbourne herbarium (MELU), the repository of the Rupp herbarium (Clarke 1990), kindly searched the collections there in vain for duplicate or other material of the species. Professor Phil GarnockJones (Victoria University of Wellington) and Dr Barbara Briggs, Joy Everett, Karen Wilson and Dr Peter Wilson (National Herbarium of New South Wales) provided useful criticism of the manuscript. 


\section{References}

Barker W.R. (1982) Taxonomic studies in Euphrasia L. (Scrophulariaceae). A revised infrageneric classification, and a revision of the genus in Australia. J. Adelaide Bot. Gard. 5: 1-304.

Barker W.R. (1987) Taxonomic studies in Euphrasia L. (Scrophulariaceae). V. New and rediscovered taxa, typifications, and other notes on the genus in Australia. J. Adelaide Bot. Gard. 10: 201-221.

Barker W.R. (1996) Taxonomic studies in Euphrasia L. (Scrophulariaceae), VII. A new species and a widely disjunct population from south-east Tasmania. J. Adelaide Bot. Gard. 17: 217-221.

Briggs J.D. \& Leigh, J.H. (1988) Rare and Threatened Australian Plants, revised edition. Australian National Parks \& Wildlife Service, Special Publication No. 14. Canberra.

Briggs J.D. \& Leigh, J.H. (1996) Rare or Threatened Australian Plants, 1995 revised edition. (CSIRO Publishing: Collingwood).

Clarke I.C. (1990) The history of the herbarium, School of Botany, University of Melbourne. Pp. 13-21 in P.S. Short (ed.), History of Systematic Botany in Australasia (Australian Systematic Botany Society, c/- National Herbarium of Victoria: South Yarra).

Collier, P.A. (1990) Rare taxa in the genus Euphrasia L. from lowland south-eastern Tasmania. Tasmanian Naturalist 103: 1-5.

Manuscript received 2 April 1997 Manuscript accepted 15 August 1997 